2. Касинюк Л.А., Мельник Е.А. Правова держава та проблеми становлення її в україні. Юридичний науковий електронний журнал. 2019. № 6. C. 28-32.

3. Конституція України. Відомості Верховної Ради України. 1996, № 30, ст. 141. URL: https://zakon.rada.gov.ua/

4. Маменко Б. М., Пархоменко-Куцевіл О. І. Передумови, ознаки і шляхи формування правової держави. Інвестиції: практика та досвід. 2021. № 17. С. 99-105.

5. Малишев Б.В. Принципи панування права (the rule of law) у праці Альберта Дайсі «Вступ до вивчення конституційного права». Проблеми філософії права. 2008. T. VI-VII. C. 118-123.

6. Чукаєва В. О. Громадянське суспільство та конституційна доктрина розвитку правової держави україни. Актуальні проблеми вітчизняної юриспруденції. 2019. № 3. С. 36-38.

DOI https://doi.org/10.30525/978-9934-26-148-0-8

\title{
НАСИЛИЕ И ВЛАСТЬ: ПРОБЛЕМА КОНТРОЛЯ
}

\section{Леонов Б. Д.}

доктор юридических наук, старший научный сотрудник, профессор кафедры права

Международного классического университета имени Пилипа Орлика

\section{Исмайлова А. И.}

соискатель высшего образования II курса обучения спечиальности 081 Право

Международного классического университета имени Пилипа Орлика г. Николаев, Украина

Классическая постановка вопроса о власти заключается в том, что она представляет собой совокупность политических институтов, посредством функционирования которых одни социальные группы получают возможность навязывать свою волю другим и действовать в соответствии с так называемыми общими (общенародными, общегосударственными) интересами [1, с. 273].

Изначально создание государства обуславливается потребностью политической организации власти народа. Однако, как справедливо отмечает В.Ф.Антипенко, из реального обладателя такой власти, «держателя» нации, гаранта ее целостности и безопасности оно в силу 
первородности власти по отношению к этой нации, превращается в своеобразного менеджера в международном пространстве, лоббиста интересов крупного капитала, наделяемого функциями обеспечения последнего доступа к ресурсам, технологиям, размещения инвестиций и т.п. [2, с. 37]

Конфликтогенность власти в целом достаточно глубоко исследована. В современных условиях власть все больше в большей мере является предметом самоценности не только благодаря тому, что она открывает доступ к распределению материальных ресурсов, но в силу того, что с помощью власти предлагается и утверждается определенная интерпритация жизненного мира [2, с. 54]. Публичная власть усиливается по мере того, как обостряются классовые противоречия внутри государства, и по мере того, как соприкасающиеся между собой государства становятся больше и населеннее [3]. Поэтому власть не только «отражает интересы», она творит новые отношения, она конструирует социальный мир, модифицируя социальное пространство[4, с. 155-156]. Однако оценивая понятие и содержание поведения государства, не следует впадать в две характерные крайности. С одной стороны, неправильным было бы считать, что государство проявляется лишь в поступках, действиях людей и даже через действия. С другой недопустима безоглядная абстракция, когда государство, его деятельность представляються как некий продукт общей воли народа, реализуемой органами и институтами государства.

Предоположив, что государство располагает принудительной силой, мы должны признать, что лица, управляющие государством, будут использовать эту силу в своих интересах за счет остального общества. Однако на нынешнем уровне знаний нам неизвестно как создать такое государство. Некоторые ученые видят решение этой проблемы в следующем: правильное составленная конституция ограничивает тираническое злоупотребление политической властью.

Другие ученые не скрывают свого скептического отношения. Наиболее распространённое представление о власти как продукта определённого общества, сформированного для потребностей собственной организации. Есть смысл подробнее остановиться на этой проблеме и высказаться в поддержку точки зрения выдающегося французского социолога Бертран де Жувенеля, который небезоно-вательно считал, что власть как самогенерирующий механизм повеливания первородна по отношению к обществу, поскольку она формирует социум «под себя» [5]. Именно власть выстраивает сложный механизм государства, в котором соответствующий апарат задает функции органам государства, общественным институтам, индивидам и народу в целом $[2$, с. 36,58$]$. В юридической науке такой поход привлекает все большее внимание. 
Все дело конечно в том, что считать первичным. То есть вопрос заключается в следующем: первично ли содержание политических правил по отношению к обществу или состояние общества обуславливает содержание государства. На первый взгляд, это похоже на вопрос о том, что было раньше: яйцо или курица? Кажется вероятным, что именно государство формирует новые свойства общества. Следовательно, содержательные характеристики поведения, в том числе способность и свойства, продуцирующие конфликт, государству придает, как правило, не народ, а реально правящая коалиция элиты. Поэтому соверешенно не случайно, что современные элиты под системной бюрократической опекой вырождаются, деградируют, и утрачивают ту свою аристократическую сущность, которая исторически обеспечивала им ведущую роль в обществе. Тронутые эрозией морального и духовного упадка, элиты подрывают в общественном мнении авторитет государства, котрое они в прошлом олицетворяли [2, с. 8]. В результате, во-первых, это ведет к деградации общественной морали, во-вторых, государство превращается в открытого лоббиста интересов этих самых элит в сфере обеспечения ресурсов, выгодного размещения инвестиций, обеспечения благоприятных условий кридитной политики и т.п., a, в-третьих, на вооружение государств поступают мощные механизмы тотального контроля над обществом, которые формируются на базе информационно-коммуникационных технологий. Конфликтность элиты, его поведения следует в большинстве случаев связывать с ситуацией, когда его механизм начинает действовать вне общества (народа), вопреки чаяниям и сущности общества, вплоть до состояния враждебности обществу (народу) [2, с. 8-9]. Именно власть, создав в современном обществе ситуацию предельной социально-экономической поляризации, результивировала протестные настроения огромных людских масс. Она же, прикрываясь благопристойними намерениями демократизации традиционных обществ, дезитегрирует их в и в целях удобства контроля создает повсеметсно очаги напряжения, кровавых конфликтов [2, с. 29]. Реализация членами правящей коалиции таких намерений с помощью возможностей государства помогает сохранить контроль над властью.

Таким образом, власть и насилие контролируются господствующей коалицией, которая вынуждена поддерживать хрупкий баланс между членами этой коалиции.

Современная теория политики должна объяснить распределение и использование власти, насилия и принуждения внутри общества, a теория правительства должна объяснить как структуру правительственного аппарата, так и поведение чиновников и иных служащих государства [6].

Б. Вайнгаст, Д. Норт и У.Джон предлагают новый способ осмысления политического развития, который предполагает акцент на 
таких способностях государства, как: поддержание сложных и специализированных организаций, установление обезличенных отношений, обеспечение работы бессрочно существующего государства, а также контроль над дисперсией и испольованием насилия в обществе[6]. Этот подход открывает новые концептуальные рамки общественно-научного исследования, подрузамивающее более глубокое понимание природы насилия.

\title{
Литература:
}

1. Антипенко В.Ф. Теории мирового развития и антитеррористическое право. Логика сопрягаемости. К., 2007. 440 с.

2. Антипенко В.Ф. Теория уголовной ответственности государств : монография. Одесса: «Фенікс», 2016. 328 с.

3. Энгельс Ф. Происхождение семьи, частной собственности и государства: В связи с исследованиями Льюиса Г. Моргана. Москва: Издательство политической литературы, 1982. 240 с.

4. Здравомыслов А.Г. Социология конфликта: Россия на путях преодоления кризиса: пособ. М.: АсистПресс, 1994. 318 с.

5. Жуневель Б. Власть: Естественная история ее возрастания. М.: ИРИСЭН. Мысль. 2011. 546 с.

6. Норт Д., Уоллис Д., Вайнгаст Б. Насилие и социальные порядки. М.: Изд-во Института Гайдара, 2011. 482 с.

DOI https://doi.org/10.30525/978-9934-26-148-0-9

\section{ТРАНСПЛАНТАЦІЯ: ОСНОВНІ ПІДХОДИ ДО РОЗУМІННЯ}

\section{Попович Т. П.}

кандидат юридичних наук, дочент, доцент кафедри теорії та історії держави і права ДВНЗ «Ужгородський національний університет»

\section{Ільченко С. О.}

аспірант кафедри теорії та історії держави і права ДВНЗ «Ужгородський національний університет»

\author{
м. Ужгород, Україна
}

Трансплантація являє собою складний процес, що містить два основні етапи: перший - забір органів і тканин від донора, другий імплантацію останніх в організм реципієнта. При цьому, варто наголосити, що трансплантація може бути здійснена лише в тому 